\title{
TANGGUNGJAWAB PERUSAHAAN EKSPEDISI TERHADAP KERUSAKAN DAN KEHILANGAN BARANG MUATAN DALAM PENGANGKUTAN DARAT
}

\author{
Ketut Arie Jaya, I Nyoman Putu Budiartha, Ni Made Puspasutari Ujianti \\ Fakultas Hukum Universitas Warmadewa, Denpasar - Bali, Indonesia
}

\begin{abstract}
Abstrak
Tanggungjawab Perusahaan Ekspedisi Muatan dalam pengangkutan niaga tidak mudah di mana resiko-resiko dan kejadian seperti kerusakan dan kehilangan yang terjadi pada barang muatan sangat rentan untuk terjadi sehingga Perusahaan Ekspedisi mengalami kerugian. Penelitian ini bertujuan untuk menganalis faktor-faktor yang menyebabkan terjadinya kerusakan dan kehilangan barang muatan dalam pengangkutan darat dan mengetahui tanggung jawab perusahaan ekspedisi terhadap kerusakan dan kehilangan barang muatan dalam perjanjian pengangkutan niaga di darat. Metode yang digunakan dalam penelitian ini yaitu metode penelitian empiris dengan pendekatan sosiologis hukum. Ada dua jenis data yang digunakan dalam penelitian ini yaitu data primer dan data sekunder. Teknik yang digunakan dalam pengumpulan data yaitu wawancara yang dilakukan kepada para informan yang ada di PerusahaanEkspedisi, PT. Indah Cargo Logistic, Denpasar. Hasil penelitian menunjukan bahwa ada dua faktor yang menyebabkan pengangkutan barang rusak atau hilang yaitu factor kesalahan sistem, kesalahan kasir, adminitratasi, terjadi penyusutan, terjadinya fraud atau kecurangan dari staff perusahaan. Kesalahan penempelan label atau alamat. Sementara kaktor eksternal meliputi faktor alam seperti cuaca yang buruk atau hujan, faktor kecelakaan lalu lintas, factor begal atau pencuri, factor jalan yang rusak sehingga barang menjadi rusak di dalam mobil. Dari hasil penelitian ini, merekomendasikan bahwa prinsip tanggungjawab karena kesalahan serta prinsip tanggungjawab karena praduga sangat tepat diberlakukan dalam kegiatan pengangkutan barang di Indonesia karena selain melindungi kepentingan pengirim dan penerima barang juga memberi rasa aman kepada pihak pengangkut dalam menjalakan tugasnya.
\end{abstract}

Kata Kunci: Tanggungjawab; Perusahaan Ekspedisi; Kerusakan dan Kehilangan.

\begin{abstract}
Responsibilities of Freight Forwarding Companies in commercial transportation are not easy where risks and events such as damage and loss that occur on cargo goods are very vulnerable to occur so that the Expedition Company suffers losses. This study aims to analyze the factors that cause damage and loss of cargo in land transportation and determine the responsibility of shipping companies for damage and loss of cargo in commercial transportation agreements on land. The method used in this study is an empirical research method with a sociological approach to law. There are two types of data used in this study, namely primary data and secondary data. The technique used in data collection is interviews conducted with informants in the Expedition Company, PT. Indah Cargo Logistic, Denpasar. The results showed that there were two factors that caused the transportation of damaged or missing items, namely system error, cashier error, administration, shrinkage, fraud or fraud from company staff. Label or address attachment error. While external factors include natural factors such as bad weather or rain, traffic accidents, thieve factors, damaged road factors that cause goods to become damaged in the car. From the results of this study, it recommends that the principle of responsibility due to errors and the principle of responsibility due to presumption is very appropriate to be applied in the activities of transporting goods in Indonesia because in addition to protecting the interests of the sender and recipient of goods also gives a sense of security to the transporter in carrying out his duties.
\end{abstract}

Keywords: Damage and Loss; Expedition Company; Responsibility

\section{PENDAHULUAN}

Pengangkutan merupakan rangkaian kegiatan pemindahan penumpang atau barang dari satu tempat pemuatan ke tempat tujuan sebagai tempat penurunan penumpang atau pembongkaran barang muatan. Rangkaian peristiwa pemindahan itu meliputi kegiatan: memuat penumpang atau barang ke alat pengangkut, Membawa barang atau penumpang ke tempat tujuan, dan Menurunkan penumpang atau membongkar barang di tempat tujuan (Muhammad, 2008). Pengangkutan yang meliputi tiga kegiatan 
ini merupakan satu kesatuan proses yang disebut pengangkutan dalam arti luas. Pengangkutan juga dapat dirumuskan dalam arti sempit. Disebutkan dalam arti sempit karena hanya meliputi kegiatan membawa penumpang atau barang dari stasiun/terminal/pelabuhan/bandara tempat pemberangkatan pengangkutan dalam arti luas atau arti sempit bergantung pada perjanjian pengangkutan yang dibuat oleh pihak-pihak, bahkan kebiasaan masyarakat.

Perjanjian timbal balik antara pengangkutan dan pengiriman dimana pengangkutan mengikatkan diri untuk menyelenggarakan pengangkutan barang atau orang di suatu tempat ke tempat tujuan tertentu dengan selamat. Sedangkan pengirim mengikatkan diri untuk membayar uang angkutan (Purwosutjipto, 1994). Perjanjian adalah sumber perikatan, perikatan yang berasal dari perjanjian dikehendaki oleh dua orang atau dua pihak yang membuat perjanjian, sedangkan perikatan yang lahir dari undang- undang dibuat atas dasar kehendak yang berhubungan dengan perbuatan manusia yang terdiri dari dua pihak (Suharnoko, 2004).

Perusahaan Ekspedisi Muatan bertugas untuk mengangkut barang muatan dari gudang pengirim dan melakukan packing/pengemasan sesuai dengan jenis barang muatan. Beberapa hal berikut yang bisa dijadikan pertimbangan dalam proses pengiriman barang adalah jenis packing/pengemasan maupun kekuatan packing sangat mempengaruhi apakah barang muatan tersebut bisa selamat tiba ke tempat tujuan tanpa kerusakan yang berarti. Dalam proses packing ini perlu dilihat beberapa hal seperti jenis barang yang hendak dikirim tersebut apakah termasuk dalam kategori pecah belah, cairan, makanan, dan sebagainya.

Beberapa perusahaan ekspedisi tidak mau mengangkut barang pecah belah jika packing yang dibuat ternyata tidak kuat. Untuk barang pecah belah biasanya dilakukan packing tambahan berupa packing berbahan kayu. Selanjutnya mengurus dokumen barang muatan yang sering disebut dengan konosemen agar tepat, jelas dan sesuai dengan keadaan barang muatan. Konosemen ini berisikan keterangan pengirim barang, penerima barang, penerima uang, tujuan pengiriman barang dan sebagainya. Setelah tahapan-tahapan tersebut diselesaikan, Perusahaan Ekspedisi Muatan kemudian mengangkut barang menggunakan transportasi. Apabila ternyata belum mendapatkan pengangkut, Perusahaan Ekspedisi Muatan Darat akan menyimpan barang muatan tersebut terlebih dahulu di gudang. Perusahaan Ekspedisi Muatan dituntut memiliki transportasi berkapasitas baik dalam mengangkut barang muatan sehingga barang dapat sampai di tempat tujuan dengan selamat. Dalam kepustakaan terdapat berbagai istilah untuk menyebut benda/barang yang diangkut yaitu goods, merchandise, dan cargo. Dalam pengangkutan udara berarti segala sesuatu benda apapun jenisnya yang diangkut dengan pesawat, selain benda- benda pos, bagasi tangan, bagasi tercatat (Suriaatmadja, 2005). Ada beberepa penelitian yang telah dilakukan terkait dengan permasalahan yang diteliti saat ini. Pertama, Suryono \& Isnaini (2009) dalam penelitiannya menyatakan bahwa tuntutan penggantian kerugian oleh pengguna jasa terminal petikemas baik dari pihak pengirim barang maupun penerima barang, biasanya terjadi pada saat barang diserahkan dari pengangkut kepada sipenerima setelah petikemas ditumpuk dilapangan penumpukan karena adanya kekurangan jumlah barang atau terjadi kerusakan pada barang ataupun petikemas. Kedua, Fatahillah (2015) mengatakan bahwa terkait penyelesaian sengketa yang ditempuh akibat kerusakan dan kehilangan barang untuk mendapat haknya kembali bisa dilakukan upaya musyawarah sehingga menghasilkan kesepakatan antara para pihak. Dengan kesepatan begini, masing-masing pihak saling menguntungkan demi menjaga nama baik dari perusahaan jasa angkutan dan pengguna jasa tidak terlalu dirugikan. Selanjutnya, (Nabila, 2015) mengatakan bahwa perjanjian pengangkutan adalah perjanjian timbal balik antara pengangkut dengan pengirim, dimana pengangkut mengikatkan dirinya untuk menyelenggarakan pengangkutan barang dan atau orang dari suatu tempat ke tujuan tertentu dengan selamat, sedangkan pengirim mengikatkan diri untuk membayar uang angkutan.

Sebagaimana yang telah diketahui bahwa peraturan perundang-undangan mengatur beberapa kewajiban yang harus dipatuhi oleh perusahaan pengangkutan dalam menjalankan usahanya sebagaimanayang dijelaskan. Apabila dalam melaksanakan kewajibannya itu terjadi pelanggaran maka tentu saja tanggung jawab sepenuhnya menjadi milik pihak Perusahaan Ekspedisi, pada intinya pihak ekspedisi bertindak sebagai perantara dan mewakili pengiriman kepada pihak pengangkut yang menjalankan tindakan hukum mengatas nama pengirim melalui hal mengangkut muatan (ekspeditur adalah pemilik usaha). Berdasarkan deskripsi di atas, maka tujuan penelitian baru ini bertujuan untuk menganalis faktor-faktor yang menyebabkan terjadinya kerusakan dan kehilangan barang muatan 
dalam pengangkutan darat dan mengetahui tanggung jawab perusahaan ekspedisi terhadap kerusakan dan kehilangan barang muatan dalam perjanjian pengangkutan niaga di darat.

\section{METODE PENELITIAN}

Metode yang digunakan dalam penelitian ini yaitu metode penelitian empiris dengan pendekatan sosiologi hukum. Ada dua jenis data yang digunakan dalam penelitian ini yaitu data primer dan data sekunder. Sumber data primer diperoleh melalui wawancara dengan pihak terkait. Sementara data sekunder diperoleh dari peraturan perundang-undangan, buku, dan jurnal penelitian yang terkait dengan permasalahan penelitian ini. Dalam memperoleh data yang valid, peneliti melakukan pemeriksaan ulang dilapangan dengan melakukan wawancara. Teknik wawancara dilakukan kepada para informan yang ada di Perusahaan Ekspedisi, PT. Indah Cargo Logistic, Indah Cargo Logistic Denpasar. Data yang terkumpul, kemudian, dianalisis dan diolah berdasarkan aturan perundanganundangan. Setelah itu, data ditampilkan dalam bentuk paragraph yang dideskripsikan melalui katakata.

\section{HASIL PENELITIAN DAN PEMBAHASAN \\ Faktor-faktor yang menyebabkan terjadinya kerusakan dan kehilangan barang muatan dalam pengangkutan darat}

Pengangkutan pada pokoknya berisikan perpindahan tempat baik mengenai benda-benda maupun mengenai orang-orang, karena perpindahan itu mutlak perlu untuk mencapai dan meninggikan manfaat serta efisiensi. Adapun proses dari pengangkutan itu merupakan gerakan dari tempat asal dari mana kegiatan angkutan dimulai ke tempat tujuan dimana angkutan itu diakhir (Soekardono, 1981). Pengangkutan melingkupi pengangkutan darat dengan kereta api atau kendaraan umum, pengangkutan perairan dengan kapal, pengangkutan udara dengan pesawat udara. Aspek hukum publik pada pengangkutan, seperti akta pendirian perusahaan, surat izin perusahaan, pendaftaraan perusahaan, pengumuman perusahaan dalam berita negara, penyedia fasilitas public, dan infrastruktur pengangkutan niaga diatur dalam undang-undang. Aspek hukum perdata pada pengangkutan, seperti kontrak carter (charter party), kewajiban dan pihak-pihak, ganti kerugian akibat wanprestasi, upaya mengatasi resiko dengan asuransi dan cara penyelesaian sangketa pengangkutan diatur dengan perjanjian yang dibuat oleh pihak-pihak dan kebiasaan yang hidup dalam masyarakat.

Pelaksanaan pengangkutan barang melalui jalur darat merupakan salah satu penyelenggaraan pengangkutan yang memiliki resiko tinggi. Hal ini disebabkan oleh beberapa kendala yang dialami oleh penyelenggara pengangkutan barang melalui jalur darat. Kendala atau hambatan dalam pengangkutan darat bisa disebabkan oleh beberapa hal, keadaan alam dan kecelakaan ataupun kerusakan mesin truk yang tidak mungkin dapat diduga dalam pelaksanaan pengangkutan barang melalui darat maka kami membatasi tanggung jawab kami dalam konosemen yang dibuat.

Faktor internal yang menjadi penyebab mengapa barang pengangkutan rusak atau hilang. Menurut informan yang telah diwawancarai pada tanggal 10 November 2019 Bapak Komang Dharmana S.H selaku Kepala Agen Otonom Indah Logistik Wilayah Denpasar mengatakan bahwa di Indah Logistic senantiasa selalu berusaha memberikan pelayanan loading (pemuatan barang) dan Unloading (pembongkaran muatan) dengan sebaik-baiknya, karena kedua proses tersebut sangatlah penting dalam upaya menghindari terjadinya kerusakan dan kehilangan barang dalam proses pengangkutan. Selain itu, faktor internal lain juda disebutkan oleh Bapak Komang adalah kerusakan barang bisa disebabkan oleh barang-barang lainnya yang berada dalam satu box container pada truk. Contohnya seperti barang yang berisi cairan yang disebabkan packagingnya/packing yang dibawah standar cairan tersebut merembes ke barang lainnya sehingga menyebabkan barang lain menjadi rusak. Dalam kasus yang lain juga bisa terjadi karena proses loading yang kurang cermat yang menjadi penyebab barang rentan dan mudah mengalami kerusakan atau pecah di posisi kan di lantai paling dasar container, karena tertindih/tertimpa barang lainnya yang dapat menjadi penyebab terjadinya kerusakan pada kemasan dan isi barang tersebut.

Faktor-faktor Eksternal penyebab terlambat atau rusaknya barang sewaktu proses mengangkut yang dihadapi Perusahaan Pengangkut dalam proses pengangkutan barang melalui jalur darat adalah sebagai berikut: 
a. Faktor alam berupa cuaca buruk atau badai. Dalam situasi hujan, penglihatan driver terganggu dan rawan terjadi kecelakaan, tidak jarang proses pengangkutan itu berhenti dengan tujuan untuk menjaga keselamatan barang.

b. Faktor kelalaian, terjadi dikarenakan kondisi dari kelalaian pengirim itu sendiri dan dari pengemudi lain.

c. Faktor tindak kejahatan dijalanan dengan cara mencuri barang yang akan dikirimkan yang dilakukan oleh seseorang atau sekelompok pencuri.

d. Faktor jalanan juga dapat berpengaruh besar dalam keselamatan barang muatan itu sendiri, jalanan yang berlubang ataupun tidak rata/rusak beresiko tinggi dapat menyebabkan kerusakan pada barang muatan seperti "barang muatan yang mudah pecah belah" maka dari itu diperlukannya melakukan penempatan/penataan barang muatan agar menekan dan mengurangi resiko terjadinya kerusakan.

\section{Tanggungjawab perusahaan ekspedisi terhadap kerusakan dan kehilangan barang muatan dalam perjanjian pengangkutan niaga di darat}

Pengertian ganti kerugian dapat dilihat pada pasal 1243 Litab Undang-undang Hukum Perdata Indonesia menyebutkan bahwa penggantian biaya, rugi, dan bunga karena tak dipenuhinya suatu perikatan barulah mulai diwajibkan, apabila siberhutang, setelah dinyatakan lalai memenuhi perikatannya, tetap melalaikannya, atau jika sesuatu yang harus diberikan atau dibuatnya, hanya dapat diberikan atau dibuat dalam tenggang waktu yang telah dilampaukannya.

Pada umumnya untuk memberikan kenyamanan dan rasa aman dalam proses pengangkutan, Perusahaan Ekspedisi akan menawarkan asuransi atau mengasuransikan barang muatan terlebih dahulu sebelum dikirim. Tujuannya adalah apabila barang tersebut mengalami kerusakan atau hilang maka kerugian yang dialami dapat meminimalisir sebab ada pihak yang bertanggung jawab sebagai penanggung. Untuk asuransi yang berupa barang umumnya disebut asuransi kerugian, yaitu ganti rugi dititik beratkan pada wujud berupa barang. Berdasarkan hasil wawancara pada tanggal 11 ebruari 2020 dengan Kepala Cabang Indah Cargo Logistic Denpasar, Bapak Ade Maryanto mengatakan bahwa "setiap customer yang datang dan mempercayakan barang kirimannya kepada Indah Cargo Logistic 100\% kami berikan dua rangkap. Sebelum lahir proses pergantian secara $100 \%$ tentu ada alur yang sudah diatur didalam SOP perusahaan. Hal pertama adalah complain harus di law kan 1x24jam, dimana jangka terima barangnya dinyatakan rusak, hilang atau bahkan tidak ada barang dihari itu juga costumer wajib melaporkan barang tersebut kepada cabang tujuan sehingga yang mengajukan complain ke pusat itu cabang asal, contoh barang dari Denpasar ke Bandung dan sampainya di Bandung barang diterima tidak sesuai misalkan rusak, kurang satu, atau bagaimana si penerima harus menghubungi pengirim, sehingga pengirim bisa mengajukan complainnya ke cabang asal di Denpasar. Di Denpasar harus melahirkan berita acara dengan costumer cabang tujuan untuk tidak tanda tangan resi tanda terima jika barang tidak sesuai, ketika semua alurnya sudah ketemu berita acara di cabang tujuan ada, penerima ada dan kurirnya ada kemudian pelaporannya tidak melebihi $1 \times 24$ jam data tersebut adalah data yang akan kami naikan ke tim remedial pusat, tim remedial merupakan tim khusus yang menangani terkait complain barang yang diajukan claimnya dari cabang asal ke pusat. Sehingga yang menentukan barang ini diganti 100\%, diganti setengah, atau diganti bagamainapun itu dikerjakan oleh tim remedial pusat, dan pada intinya pihak dari Indah Cargo Logistic akan mengganti barang kiriman yang sudah dipercayakan kepada Indah Logistic Cargo akan diganti $100 \%$ dan berapa pun nilainya.

Bagaimana mekanisme perusahaan Indah Logistic dalam menentukan besarnya ganti kerugian/nilai terhadap hilang atau rusaknya barang. Menurut Bapak Ade Maryanto selaku Kepala Cabang Indah Cargo Logistic Denpasar, yang pertama adalah melihat nilai Taksasi barang, melalui resi yang menjadi alat transaksi barang ada yang namanya nilai Taksasi. Nilai Taksasi adalah nilai perkiraan harga barang tersebut dan didukung oleh faktor-faktor pembelian, nota-nota pembelian, struk-struk pembelian atas barang kiriman tersebut, sehingga pihak Indah Logistic bisa mengeluarkan keputusan untuk mengganti $100 \%$ nilai taksasi barang tersebut. Contoh: Barang pindahan berupa kulkas yang misalkan rusak atau hilang senilai 500ribu rupiah maka akan diganti dengan nominal yang sama jika memang itu dinyatakan dari berita acara yang lahir dari kedua belah pihakmendukung untuk diadakan pergantian, jika hasil temuan tim remedial berbanding terbalik dengan harapan costumer pasti memiliki alasan misalkan ketika kurir melakukan penjemputan sebuah kulkas atau 
barang pecah belah, kurir pasti menawarkan untuk di packing jika costumer menolak atau mengatakan tidak perlu dan dikemudian hari ada kerusakan maka pihak Indah Logistic wajib mengeksekusi dalam artian ditangani, kurir wajib mengeluarkan surat formulir bahwa barang tidak diganti atau barang no claim. Sehingga ketika terjadi kerusakan atas barang tersebut secara the facto barang tersebut tidak bisa diganti. Adapula penyelesaian melalui pengadilan namun biasanya jarang terjadi, pengirim biasanya enggan untuk menempuh jalur pengadilan dikarenakan memerlukan biaya yang tidak sedikit dan juga butuh waktu yang lama dan berbelit-belit. Bahkan mungkin saja biaya pengadilan tersebut dapat melampaui nilai barang itu sendiri.

Jika penyelesaian ganti kerugian diluar pengadilan cenderung dilakukan sebagai pilihan penyelesaian ganti rugi dalam sangketa pengangkutan mengingat syaratnya yang cepat tanpa perlu melewati birokrasi atau administrasi yang berbelit-belit, mudah untuk dilakukan yaitu kapan waktu yang diingankan para pihak untuk menyelesaikan permasalahan, dan putusannya menjunjung asas win-win solution, bahwa tidak ada pihak yang merasa dirugikan berdasarkan kesepakatan yang telah disetujui oleh para pihak. Mengingat kerjasama pengangkutan merupakan kerjasama yang berdimensi bisnis maka pelayanan dan kesan yang baik dalam memberikan dan menawarkan jasa pengangkutan senantiasa selalu dijaga demi eksistensi perusahaan itu sendiri. Jadi dengan menempuh jalur Non Litigasi ini, para pihak dikemudian harinya tetap dapat menjalin hubungan yang baik dan harmonis, dan yang lebih penting adalah para pihak yang sebelumnya bersengketa dikemudian hari tetap bersedia dan percaya untuk menjalin kerjasama pengangkutan barang.

\section{SIMPULAN DAN SARAN}

1. Simpulan

Ada beberapa faktor internal dan eksternal yang menyebabkan barang pengangkutan rusak atau hilang, faktor internalnya antara lain: Barang hilang karena dicuri, hilang karena kesalahan system, hilang karena kesalahan administrasi, berkurangnya nilai karena penyusutan. Barang rusak maka kasir yang salah. Terjadinya fraud atau kecurangan dari staff perusahaan. Kesalahan penempelan label atau alamat. Faktor eksternal yang menjadi penyebab barang pengangkutan rusak atau hilang, antara lain: berupa faktor alam seperti cuaca yang buruk atau hujan. Dalam keadaan hujan maka jarak pandang dari pengemudi sangat terbatas dan sangat rawan terjadi kecelakaan, tidak jarang proses pengangkutan itu dihentikan dengan tujuan untuk menjaga keselamatan barang. Ada juga berupa faktor kecelakaan lalu lintas, hal ini bisa terjadi karena kondisi dari kelalaian pengemudi itu sendiri dan dari pengemudi lain, faktor tindakan kejahatan dijalanan dengan cara mencuri barang yang akan dikirimkan yang dilakukan oleh seseorang atau sekelompok pencuri, dan yang terakhir faktor jalanan juga dapat berpengaruh besar dalam keselamatan barang muatan itu sendiri, jalanan yang berlubang ataupun tidak rata/rusak beresiko tinggi dapat menyebabkan kerusakan pada barang muatan seperti "barang muatan yang mudah pecah belah" maka dari itu diperlukannya melakukan penempatan/penataan barang muatan agar menekan dan mengurangi resiko terjadinya kerusakan.

\section{Saran}

Dari pemaparan keseluruhan hasil penenlitian di atas, maka peneliti menyarankan sebagai berikut. Prinsip tanggungjawab karena kesalahan serta prinsip tanggungjawab karena praduga sangat tepat diberlakukan dalam kegiatan pengangkutan barang di Indonesia karena selain melindungi kepentingan pengirim dan penerima barang juga memberi rasa aman kepada pihak pengangkut dalam menjalakan tugasnya. Meskipun pada praktiknya perusahaan ekspedisi (Indah Cargo Logistic) memberikan ganti kerugian jika ada barang yang hilang ataupun mengalami kerusakan, hendaknya perusahaan ekspedisi (Indah Cargo Logistic) senantiasa bekerja sesuai dengan standar yang berlaku dalam menangani barang muatan, mengingat tanggung jawab yang dipikul oleh perusahaan tidaklah ringan.

\section{DAFTAR PUSTAKA}

Fatahillah. (2015). Pengaturan Perlindungan Hukum Terhadap Pengguna Jasa Transportasi di Darat atas Kehilangan dan Kerusakan Barang Kiriman. Jurnal Ilmu Hukum Reusam, 4(1), 89-103.

Muhammad, A. (2008). Hukum Pengangkutan Niaga. Bandung: Citra Aditya Bakti.

Nabila. (2015). Wanprestasi pada Suatu Bill of Lading dalam Pengangkutan Barang melalui Laut. Pakuan Law Review, 1(2), 61-112.

Purwosutjipto. (1994). Pengertian Pokok Hukum Dagang Indonesia. Jakarta: Djambatan. 
Soekardono, R. (1981). Hukum Dagang Indonesia (2nd ed.). Jakarta: Rajawali Pers.

Suharnoko. (2004). Hukum Perjanjian. Jakarta: Prenada Media Group.

Suriaatmadja, T. (2005). Pengangkutan Kargo Udara. Bandung: Pustaka Bani Quraisy.

Suryono, \& Isnaini. (2009). Tuntutan Ganti Rugi Atas Kehilangan Barang di dalam Container Oleh Pengguna Jasaterminal Petikemas Belawan PT (Persero) Pelabuhan Indonesia I. Jurnal Mercatoria, 2(2), 128-140. 